\title{
Characteristics and causes of the inadequate corpus luteum
}

\author{
M. G. Hunter \\ AFRC Research Group on Hormones and Farm Animal Reproduction, University of Nottingham, \\ Faculty of Agricultural \& Food Sciences, Sutton Bonington, Loughborough, Leics LEI2 $5 R D$, UK
}

\begin{abstract}
Summary. An inadequate luteal phase occurs in domestic ruminants in several physiological situations (e.g. puberty, post partum), and also following the induction of ovulation in anoestrous ewes with GnRH treatment. The induced corpora lutea (CL) initially developed, but then regressed rapidly after Day 4 , unless the animals had been primed with progesterone before GnRH therapy or hysterectomized. Significant increases in prostaglandin F-2 $\alpha$ metabolite (PGFM) secretion and coincident peaks of oxytocin and PGFM occurred around the time of premature regression. Endometrial oxytocin receptors were also detectable at this time in ewes which had abnormal luteal phases, but not in ewes which had been progesterone primed and thus had normal luteal phases. This suggests that the presence or otherwise of the oxytocin receptor during the early luteal phase may be crucial in determining whether the CL has a short or normal lifespan.

These results show that an inadequate luteal phase is often caused by the premature induction of luteolysis and the presence of the endometrial oxytocin receptor is necessary for this occurrence. This receptor in turn is controlled by the steroid environment to which the uterus has previously been exposed.
\end{abstract}

Keywords: corpus luteum; inadequate; anoestrous ewe; $\mathrm{GnRH}$; oxytocin receptor

\section{Introduction}

Inadequate or abnormal luteal function occurs naturally in several physiological situations in domestic ruminants such as at puberty, post partum, the start of the breeding season, and after raminduced ovulation (Walton et al, 1977; Oldham \& Martin, 1979; Knight et al., 1981; Lamming et al., 1981; Keisler et al., 1983; Wise et al., 1986; Braden et al., 1989a) and is considered to contribute significantly to infertility. Similar abnormal corpora lutea $(C L)$ can also be produced following the induction of ovulation by GnRH treatment of anoestrous ewes (O'Shea et al., 1984; Legan et al., 1985; Southee et al., 1988a) and post-partum cows (Kesler et al., 1981; Garcia-Winder et al., 1986; Braden et al., 1989b). The ability to induce these abnormal CL therefore presents an opportunity to study in detail the mechanisms involved in the inadequacy of these tissues, and to elucidate methods for preventing or overcoming such insufficiencies. In this paper I describe such experiments using the GnRH-treated anoestrous ewe as a model.

\section{Progesterone secretion by the abnormal corpus luteum}

As reviewed by Garverick \& Smith (1986), luteal insufficiency can be divided into two major classes based on characteristics of plasma progesterone secretion. These are produced either by corpora lutea which have a short lifespan and thus show only a transient increase in progesterone secretion (Lamming et al., 1981; Southee et al., 1988a) or by corpora lutea which have a normal lifespan, but secrete lower levels of progesterone (Pratt et al., 1982; O'Shea et al., 1984). In general, the majority 
of inadequate $\mathrm{CL}$ which occur naturally in ruminants are those which have a short lifespan, and those with reduced progesterone secretion are usually the result of induced ovulation.

The animals described here were anoestrous ewes with $(+\mathrm{P})$ or without $(-\mathrm{P})$ progesterone pretreatment before $\mathrm{GnRH}$ treatment $(250 \mathrm{ng} / 2 \mathrm{~h}$ ) for 36 or $18-24 \mathrm{~h}$ respectively followed by a bolus injection of $125 \mu \mathrm{g} \mathrm{GnRH}$ to synchronize the timing of the LH surge. Such treatment has been found consistently to induce $100 \%$ normal CL (defined as plasma progesterone $>1 \mathrm{ng} / \mathrm{ml}$ for at least 8 days) in the $+\mathrm{P}$ ewes, and $\sim 70 \%$ abnormal $\mathrm{CL}$ (defined as a transient rise in plasma progesterone to $>0.5 \mathrm{ng} / \mathrm{ml}$ followed by a rapid decline) in the $-\mathrm{P}$ ewes (McLeod et al., 1982; Southee et al., 1988a; Hunter et al., 1988). The profiles obtained are shown in Fig, 1.

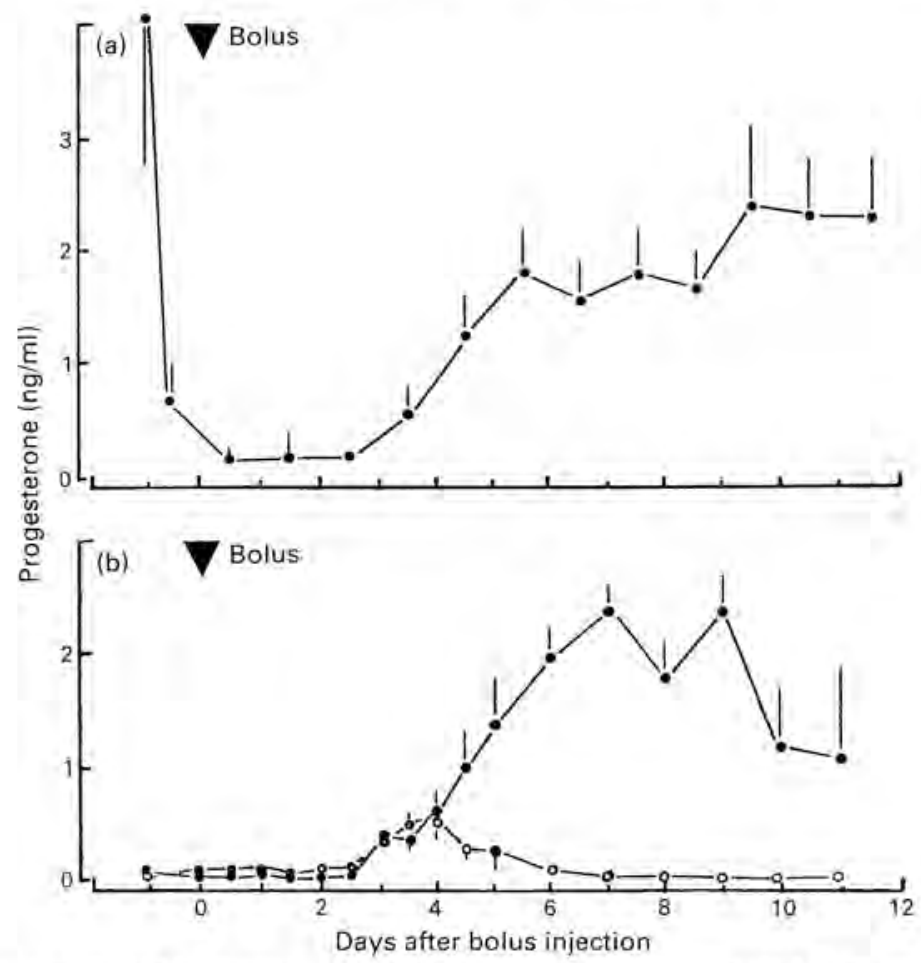

Fig. 1. Progesterone profiles (mean \pm s.e.m.) of anoestrous ewes treated with small-dose multiple injections of GnRH ( $250 \mathrm{ng}$ every $2 \mathrm{~h}$ ) plus a bolus injection of $\mathrm{GnRH}(125 \mu \mathrm{g})$ in (a) + P ewes treated for $36 \mathrm{~h}(\mathrm{~N}=5)$ and $(\mathrm{b})-\mathrm{P}$ ewes treated for $24 \mathrm{~h}$. $=$ normal luteal function $(\mathrm{N}=3) ; \mathrm{O}=$ abnormal luteal function $(\mathrm{N}=5)$. (From Hunter et al., 1988.)

\section{The role of the follicle}

Several studies have suggested that abnormal CL in sheep and cattle may be the result of inadequate follicle development before the LH surge and these are summarized in Table 1. The common characteristic of all these results is that they suggest that the follicles which are destined to form inadequate $\mathrm{CL}$ have not attained their full complement of gonadotrophin receptors or the ability to synthesize oestradiol maximally.

In the GnRH-treated anoestrous ewes described above it was noted that the $\mathrm{LH}$ surge occurred significantly later in the $+\mathrm{P}$ ewes than in the $-\mathrm{P}$ ewes (approximately 38 and $22 \mathrm{~h}$, respectively, after the start of GnRH treatment: McLeod et al,, 1982; Southee et al., 1988a), suggesting that the 
Table 1. Altered development reported in follicles destined to form abnormal corpora lutea compared to those destined to form normal corpora lutea

\begin{tabular}{|c|c|c|}
\hline Species & Altered characteristics & Reference \\
\hline \multirow[t]{4}{*}{ Sheep } & $\begin{array}{l}\text { Loestradiol secretion } \\
\text { \hCG binding }\end{array}$ & Hunter et al. (1986) \\
\hline & thCG binding & Atkinson et al. (1986) \\
\hline & $\downarrow$ steroidogenic function & White et al. (1987) \\
\hline & Iblood flow & Brown et al, (1988) \\
\hline \multirow[t]{3}{*}{ Cattle } & Loestradiol in follicular fluid & Garcia-Winder et al. (1987) \\
\hline & $\begin{array}{l}\text { \LH receptors } \\
\text { \oestradiol in follicular fluid }\end{array}$ & Inskeep et al. (1988) \\
\hline & $\begin{array}{l}\text { †granulosa cell number } \\
\text { ¿ LH and FSH receptors } \\
\text { Joestradiol in follicular fluid }\end{array}$ & Braden et al. (1989b) \\
\hline
\end{tabular}

duration of follicle stimulation before the LH peak may be critical. This means that the prolonged exposure of the $+\mathrm{P}$ ewes to LH stimulation may have permitted adequate maturation of the follicle before the LH surge. However, the artificial induction of an LH surge in + P ewes after only 24 h of GnRH treatment still produced normal corpora lutea in all ewes (McLeod \& Haresign, 1984), showing that the extended period of follicle development was not crucial for subsequent adequate luteal function, but rather it may have been the prior exposure to progesterone.

Therefore, although there is extensive evidence that follicles predicted to result in luteal insufficiency have some different maturational characteristics from those which will produce normal corpora lutea, the precise mechanisms by which this causes luteal inadequacy have not been elucidated in the studies on preovulatory follicular development alone, and the involvement of the actual CL itself and other glands such as the uterus has to be considered.

\section{The early luteal phase}

We investigated in detail the characteristics of CL recovered during the early luteal phase from $+\mathrm{P}$ and - P GnRH-treated anoestrous ewes which were either normal or inadequate. As shown in Fig. 2 , initial development of both types of CL was similar until 4 days after the LH surge, but subsequently the normal CL continued to develop and then abnormal CL regressed in a manner similar to luteolysis at the end of a normal luteal phase. The same pattern was also shown in progesterone secretion in vitro (Hunter et al., 1988).

Initially, it was suggested that short-lifespan CL may have been caused by a lack of gonadotrophin receptors or of luteotrophic support. However, our own studies (Hunter et al., 1988) and those of others have shown no early decrease in $\mathrm{LH} / \mathrm{hCG}$ binding or adenylate cyclase activity (Smith et al, 1986; Braden et al., 1989b) and have demonstrated that continued treatment of anoestrous ewes with GnRH or post-partum cows with hCG did not overcome luteal insufficiency (McLeod et al., 1982; Carruthers et al., 1986). Furthermore, Garverick et al. (1988) were unable to demonstrate any differences in gonadotrophin concentrations between post-partum cattle which showed normal or subnormal luteal function. Another suggestion was that inadequate CL may have an increased sensitivity to prostaglandin (PG) F-2 $\alpha$ but this is unlikely in cows and ewes (Copelin et al., 1988; Braden et al., 1989b). Nevertheless, the finding that the abnormal CL regressed in a manner similar to those at the end of a normal luteal phase, and at the same time as the attainment of sensitivity of normal cyclic CL to the administration of exogenous PGF- $2 \alpha$, strongly suggested the involvement of the uterine luteolysin in this process. 


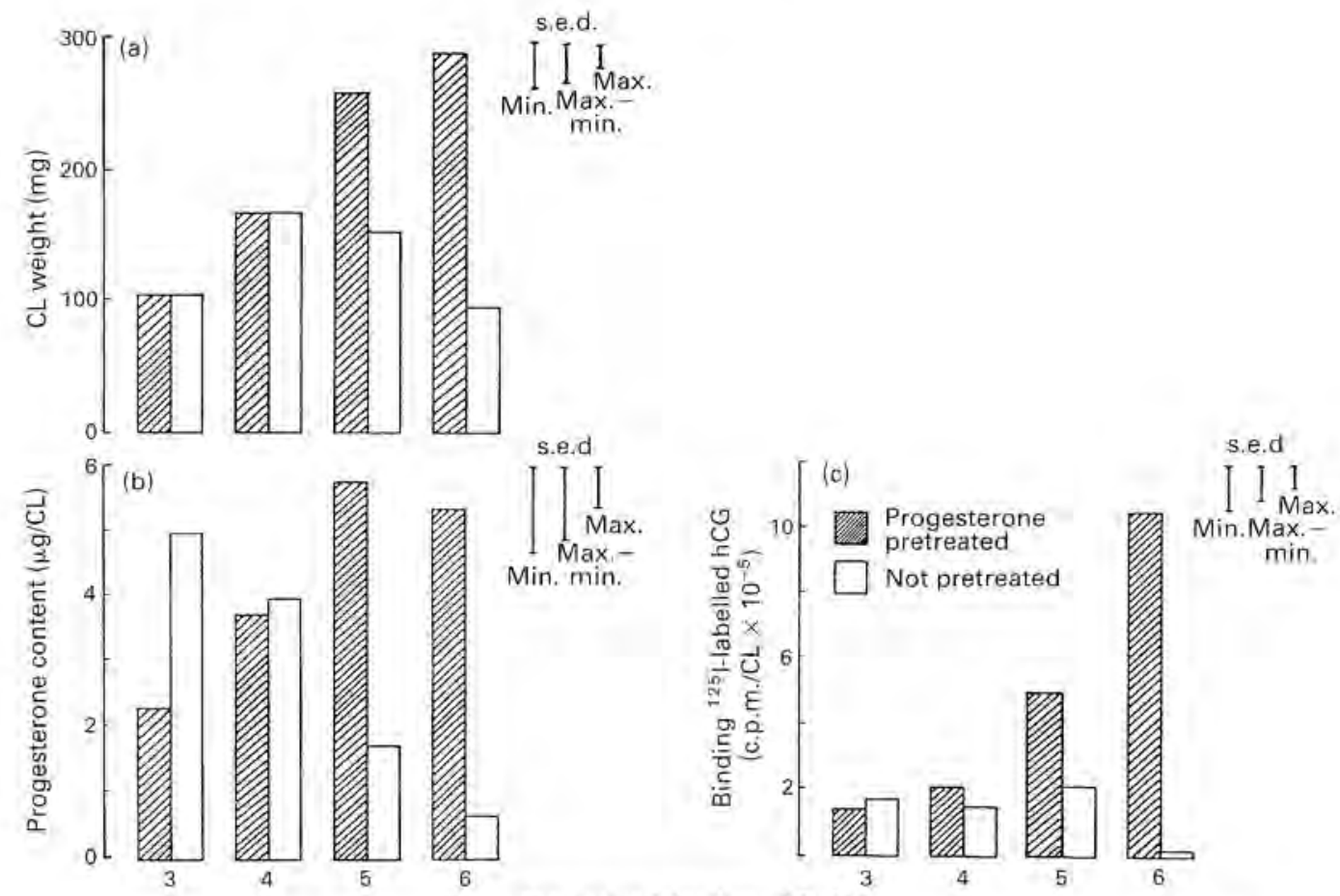

Days after bolus injection of $\mathrm{GnRH}$

Fig. 2. Mean (a) weight, (b) progesterone content and (c) binding of ${ }^{125} \mathrm{I}$-labelled hCG to corpora lutea recovered on Day $3(N=4)$, Day $4(N=11)$, Day $5(N=16)$ and Day $6(N=$ 5) following the induced LH surge from anoestrous ewes treated with injections of GnRH ( $250 \mathrm{ng}$ ) every $2 \mathrm{~h}$ plus a bolus injection $(125 \mu \mathrm{g})$ for $36 \mathrm{~h}$ after a period of progesterone pretreatment $(+P)$ (normal) or $18 \mathrm{~h}$ without pretreatment $(-P)$ (undefined normal/abnormal Days 3 and 4 ; abnormal only Days 5 and 6 ). s.e.d $=$ standard error of difference. Analysis (ANOVA) showed that the 3 characteristics measured in the two types of corpora lutea were not different on Days 3 and 4 , but by Day 5 all characteristics were significantly $(P<0.01$ at least) lower in the abnormal corpora lutea. (From Hunter et al., 1988.)

\section{The role of the uterus}

The role of the uterus in cyclic CL with a short lifespan was determined by hysterectomy of anoestrous ewes before GnRH induction of ovulation, and as shown in Fig. 3, this prevented the premature regression of abnormal CL (Southee et al., 1988b). Similar results have also been obtained in post-partum cows (Copelin et al., 1987) and ewes (Keisler et al., 1983), providing firm evidence of uterine involvement, which was further confirmed by the prevention of early regression by immunization against PGF-2 $\alpha$ (Copelin et al, 1989) or administration of indomethacin (Troxel \& Kesler, 1984).

Since the inadequate $\mathrm{CL}$ was not hypersensitive to PGF-2a (Copelin et al., 1988), it is likely that the early regression was caused by premature luteolytic release of PGF-2 $\alpha$. This was substantiated by experiments with GnRH-treated anoestrous ewes, some results of which are shown in Fig. 4. These showed an increase in PGF-2 $\alpha$ metabolite (PGFM) secretion between Days 3 and 5 in ewes with abnormal CL (some of which also contained luteinized cysts) but a decrease in those with normal CL. Furthermore, there were clear associations between major peaks of oxytocin and rises in PGFM, similar to those reported during luteolysis at the end of a normal luteal phase (Flint \& Sheldrick, 1983; Hooper et al., 1986). Also, endometrial oxytocin binding sites were detectable in 


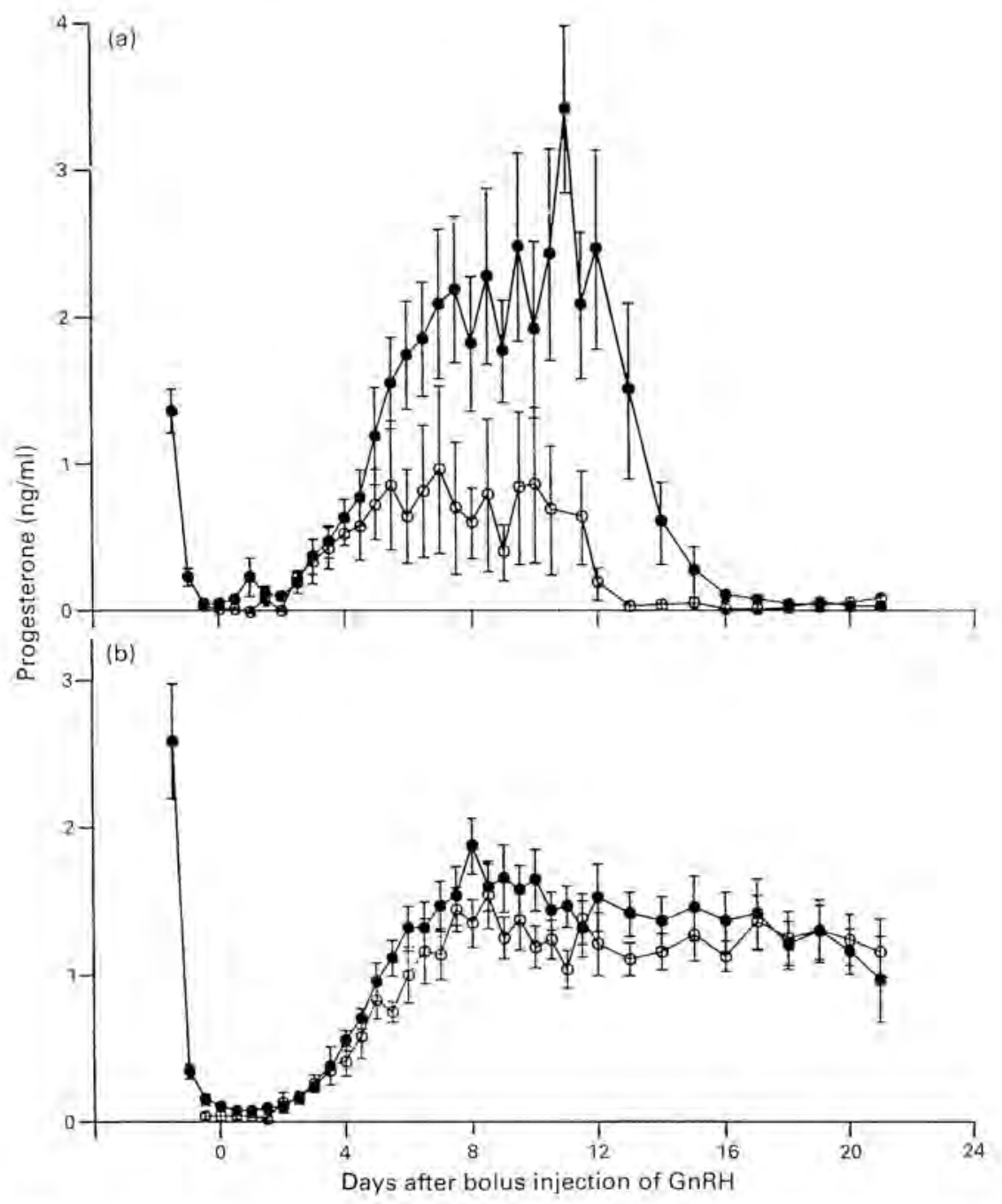

Fig. 3. Plasma progesterone profiles (mean \pm s.e.m.) of $+P(\bullet)$ and $-P(O)$ anoestrous ewes treated with multiple low-dose injections of GnRH ( $250 \mathrm{ng}$ every $2 \mathrm{~h}$ ) followed by a bolus injection of GnRH (125 $\mu \mathrm{g})$ : (a) intact ewes ( $\mathrm{N}=5 /$ group), (b) hysterectomized ewes ( $\mathrm{N}=10$ / group). For statistical analysis all $-\mathrm{P}$ ewes had to be considered as one group and so, in (a), $-\mathrm{P}$ ewes consisted of $3 \mathrm{abnormal}$ and 2 normal luteal phases. Analysis (ANOVA) showed that in (a) intact $+\mathrm{P}$ ewes had significantly higher $(P<0.05)$ plasma progesterone concentrations than did intact $-\mathrm{P}$ ewes, and that this effect was modified by hysterectomy. There were no significant differences in plasma progesterone concentrations in $+\mathrm{P}$ or $-\mathrm{P}$ hysterectomized animals, and the premature regression of abnormal corpora lutea was prevented. (From Southee et al, 1988b.)

ewes with inadequate $\mathrm{CL}$, but not in progesterone-primed ewes with normal CL. Although the oxytocin binding sites were present in concentrations lower than those reported by Sheldrick \& Flint (1985) during luteolysis, they were clearly sufficient to enable oxytocin to stimulate the release of PGF-2 $\alpha$. This suggests that the presence or otherwise of the oxytocin receptor during the early luteal phase may be crucial in determining whether the development of the CL is normal, and that 

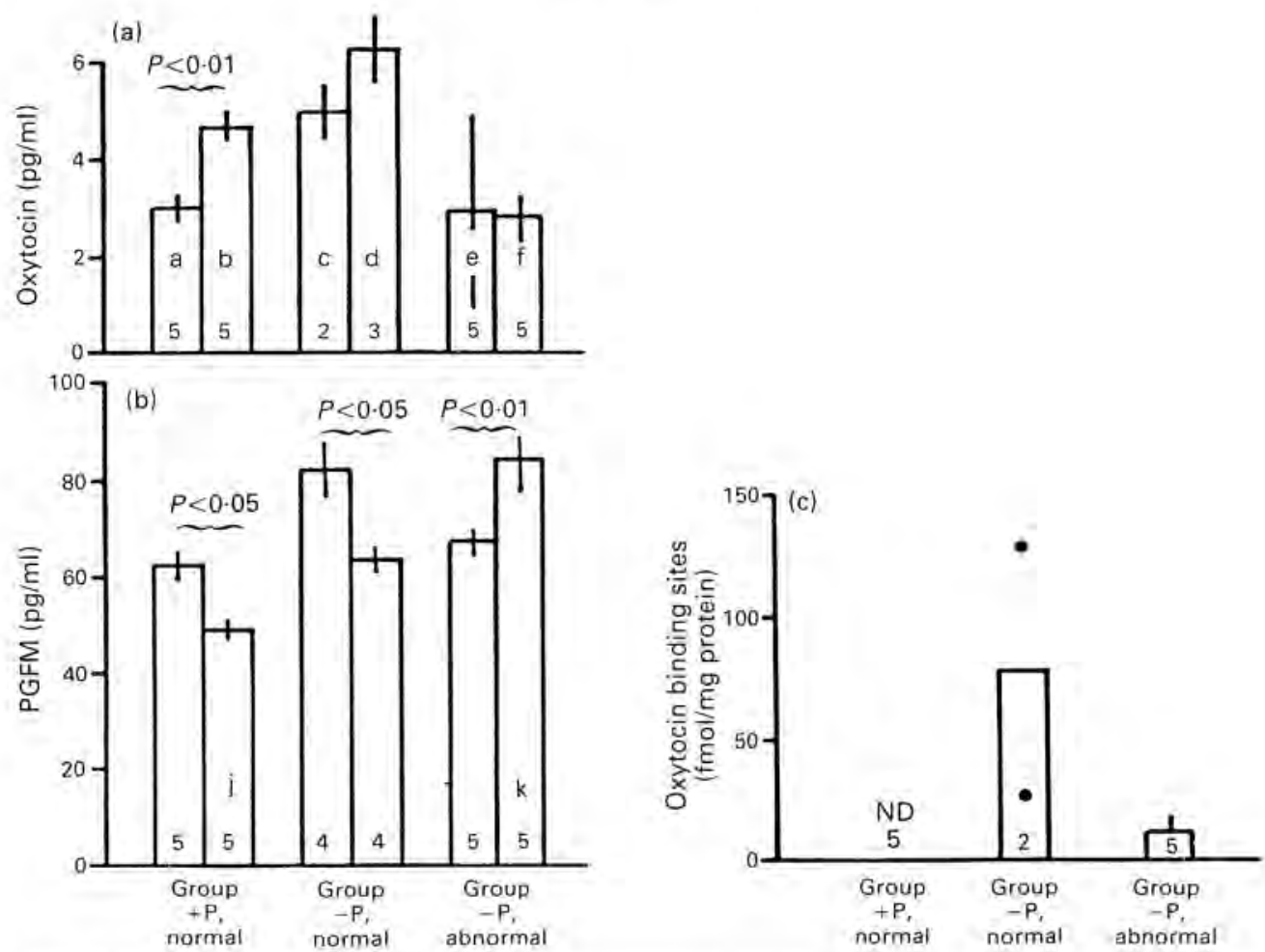

Fig. 4. Mean ( \pm s.e.m.) concentrations of (a) oxytocin, (b) PGFM and (c) endometrial oxytocin binding sites on Day 5 in anoestrous ewes treated with GnRH ( 250 ng every $2 \mathrm{~h}$ ) for $36 \mathrm{~h}$ (Group $+\mathrm{P}$ ewes) or $18 \mathrm{~h}$ (Group $-\mathrm{P}$ ewes) plus a bolus injection of $\mathrm{GnRH}(125 \mu \mathrm{g})$. Blood samples were collected every $30 \mathrm{~min}$ for $8 \mathrm{~h}$ on Days 3 and 5 . The ewes have been divided into groups on the basis of their response to treatment: Group $+\mathrm{P}$ ewes with normal CL, Group $-\mathrm{P}$ ewes with normal $\mathrm{CL}$, Group $-\mathrm{P}$ ewes with abnormal $\mathrm{CL}$ (plus luteinized cysts). The number of animals sampled per group is shown. N.D. $=$ not detectable. Significant differences (ANOVA) between days within groups are marked. Significant differences within days between groups were as follows: $\mathrm{c}>\mathrm{a}, P<0.05 ; \mathrm{d}>\mathrm{b}, P<0.05 ; \mathrm{f}<\mathrm{b}, P<0.05 ; \mathrm{f}<\mathrm{d}, P<0.01$; $\mathrm{k}>\mathrm{j}, P<0 \cdot 05$. (From Hunter et al., 1989.)

progesterone pretreatment may be important in this. Progesterone pretreatment may also influence the production of oxytocin, since plasma oxytocin concentration was significantly higher in $-\mathrm{P}$ ewes with normal CL than in $+\mathrm{P}$ ewes (Hunter et al., 1989).

\section{Progesterone and the oxytocin receptor}

The concentration of endometrial oxytocin binding sites in $+\mathrm{P}$ and $-\mathrm{P}$ GnRH-treated anoestrous ewes was similar on Day I after the LH surge $(1384 \pm 218$ and $1514 \pm 290 \mathrm{fmol} / \mathrm{mg}$ protein, respectively) but lower $(P<0.05)$ in the $+P$ animals on Day $3(443 \pm 70$ and $909 \pm 169 \mathrm{fmol} / \mathrm{mg}$ protein, respectively) (unpublished observations). This suggests a slower inhibition of oxytocin receptors in the $-\mathrm{P}$ ewes which is supported by their presence on Day 5 only in $-\mathrm{P}$ ewes (Fig. 4). The hypothesis that progesterone pretreatment affects both oxytocin receptor concentrations in the endometrium and the responsiveness to oxytocin in terms of PGF-2 $\alpha$ release was tested by Vallet $e t$ al. (1991) as summarized in Table 2. Progestagen pretreatment of ovariectomized ewes decreased 
Table 2. Treatment schedule and response of ovariectomized ewes (after Vallet et al., 1991)

\begin{tabular}{llcl}
\hline Group* & \multicolumn{1}{c}{ Treatmentt } & $\begin{array}{c}\text { Endometrial oxytocin } \\
\text { receptor concentration } \\
\text { (fmol/mg protein) }\end{array}$ & $\begin{array}{c}\text { PGFM } \\
\text { responsef }\end{array}$ \\
\hline 1 & $\begin{array}{l}\text { P priming }+\mathrm{E}_{2} \text { for } 2 \text { days }+\mathrm{P} \\
\text { for } 5 \text { days }\end{array}$ & 56 & - \\
& $\begin{array}{l}\text { P priming }+\mathrm{E}_{2} \text { for } 2 \text { days }+\mathrm{P} \\
\text { for } 5 \text { days }+\mathrm{E}_{2} \text { on Days } 4 \text { and }\end{array}$ & 293 & - \\
& 5 & 128 & - \\
3 & $\mathrm{E}_{2}$ for 2 days $+\mathrm{P}$ for 5 days & & \\
4 & $\mathrm{E}_{2}$ for 2 days $+\mathrm{P}$ for 5 days + & 758 & + \\
\hline
\end{tabular}

*4 ewes/group; standard error for oxytocin receptor concentration was 185.9 .

$\dagger$ Progestagen-primed ewes were treated with progestagen-impregnated sponges for 10 days; $E_{2}$ treatment was twice daily injections of $25 \mu \mathrm{g}$ oestradiol. $\mathrm{P}$ treatment was twice daily injections of $10 \mathrm{mg}$ progesterone.

‡PGFM response was defined as a significant increase in plasma PGFM in response to a $1 \mu \mathrm{g}$ oxytocin challenge.

Endometrial oxytocin receptor concentration was significantly higher $(P<0.05)$ in Groups $3+4$ than in Groups $1+2$. Oestradiol administration to Groups 2 and 4 increased $(P<0 \cdot 01)$ oxytocin receptor concentration compared to Groups 1 and 3 .

oxytocin receptor concentrations in endometrium from ewes treated subsequently with either progesterone for 5 days or progesterone for 5 days plus oestradiol on Days 4 and 5. Oestradiol increased endometrial oxytocin receptor concentrations when administered on Days 4 and 5 of a 5-day progesterone treatment. Oxytocin administration caused an increase in plasma PGFM concentrations only in ewes which did not receive progestagen pretreatment and subsequently received progesterone treatment for 5 days and oestradiol treatment on Days 4 and 5 (Group 4). Similarly treated ewes which did receive progestagen pretreatment did not respond to oxytocin (Group 2). These results clearly show that progesterone pretreatment affects oxytocin receptor concentrations in endometrium and uterine responsiveness to oxytocin in that the pretreatment had an enhancing effect on the inhibition of oxytocin receptors by subsequent progesterone treatment. This provides an explanation for the oxytocin receptors and PGFM episodes coincident with oxytocin release in the non-primed GnRH-treated ewe model which had a short lifecycle CL. Furthermore, oestradiol administration on Days 4 and 5 caused an increase in oxytocin-induced PGFM release in non-primed but not in primed ewes, suggesting that non-primed ewes may be more sensitive to oestradiol during the early luteal phase. This means that an increase in oestradiol concentrations due to a wave of follicular growth may have induced premature luteolysis in these ewes. It is likely that similar mechanisms operate in the post-partum cow, since Zollers $e t$ al. (1989) showed that the uterus had a greater potential to release PGF-2 $\alpha$ in response to oxytocin during the early luteal phase in cows exhibiting subnormal luteal function compared to progestagenprimed cows which had normal luteal phases. The small number $(\sim 30 \%)$ of non-primed GnRHtreated anoestrous ewes which had normal luteal phases probably did so because progesterone concentrations (of follicular or adrenal origin) before ovulation were of sufficient magnitude to ensure subsequent inhibition of the oxytocin receptor, or because folliculogenesis was disturbed and the wave of follicular growth which would produce oestradiol during the early luteal phase did not occur, or because the uterus was unable to respond to the increase in oestradiol if it did occur.

Financial support from the AFRC is acknowledged. I thank Dr B. J. McLeod, Dr W. Haresign, Dr D. C. Wathes and Dr J. L. Vallet for collaboration with some of the studies reported. 


\section{References}

Atkinson, S., Williamson, P., Kang, C.L. \& Carson, R.S, (1986) Steroid production and hCG binding by raminduced ovarian follicles in seasonally anoestrous ewes. J. Reprod. Fert. 78, 403-412.

Braden, T.D., King, M.E., Odde, K.G. \& Niswender, G.D. (1989a) Functional and morphological characteristics of the first corpus lateum formed after parturition in ewes. J. Reprod. Fert. 86, 525-533.

Braden, T.D., King, M.E., Odde, K.G. \& Niswender, G.D. (1989b) Development of preovulatory follicles expected to form short-lived corpora lutea in beef cows. J. Reprod. Fert 85, 97-104.

Brown, B.W., Cognie, Y., Chemineau, P., Poulin, N. \& Salama, O.A. (1988) Ovarian capillary blood flow in seasonally anoestrous ewes induced to ovulate by treatment with GnRH. J. Reprod. Fer1. 84, 653-658.

Carruthers, T.D., Manns, J.G. \& Rutter, L.M. (1986) Failure of human chorionic gonadotropin injections to sustain gonadotropin-releasing hormone induced corpora lutea in post-partum beef cows. Biol. Reprod. $35,846-849$.

Copelin, J.P., Smith, M.F., Garverick, H.A. \& Youngquist, R.S. (1987) Effect of the uterus on subnormal luteal function in anoestrous beef cows. $J_{+}$ Anim. Sci. 64, 1506-1511.

Copelin, J.P., Smith, M.F., Garverick, H.A., Youngquist, R.J., McVey, W.R. \& Inskeep, E.K. (1988) Responsiveness of bovine corpora lutea to PGF2 $\alpha$; comparison of corpora lutea anticipated to have short or normal lifespan. J. Anim. Sci. 66, 1236-1245.

Copelin, J.P., Smith, M.F., Keisler, D.H. \& Garverick, H.A. (1989) Effect of active immunization of prepartum and post-partum cows against prostaglandin $\mathrm{F}-2 \alpha$ on lifespan and progesterone secretion of shortlived corpora lutea. J. Reprod. Fert. 87, 199-207.

Flint, A.P.F. \& Sheldrick, E.L. (1983) Evidence for a systemic role for oxytocin in luteal regression in sheep. I. Reprod. Fert. 67, 215-225.

Garcia-Winder, M., Lewis, P.E., Deaver, D.R., Smith, V.G., Lewis, G.S. \& Inskeep, E.K. (1986) Endocrine profiles associated with lifespan of induced corpora lutea in post-partum beef cows. $J_{\text {. Anim. } S c i .62 \text {, }}$ 1353-1362.

Garcia-Winder, M., Lewis, P.E., Townsend, E.C., Lewis, G.S. \& Inskeep, E.K. (1987) Effects of norgestomet on follicular development in post-partum beef côws. J. Anim. Sci. 64, 1099-1109.

Garverick, H.A. \& Smith, M.F. (1986) Mechanisms associated with subnormal luteal function, $J$. Anim. Sci. 62, Suppl. 2, 2546.

Garverick, H.A., Parfet, J.R., Lee, C.N., Copelin, J.P., Youngquist, R.S. \& Smith, M.F. (1988) Relationship of pre-and post-ovulatory gonadotropin secretion to subnormal luteal function in post-partum beef cattle. J. Anim. Sci. 66, 104 111.

Hooper, S.B., Watkins, W.B. \& Thorburn, G.D. (1986) Oxytocin, oxytocin-associated neurophysin and prostaglandin F2 $\alpha$ concentrations in the uteroovarian vein of pregnant and non-pregnant sheep. Endocrinology 119, 2590-2597.

Hunter, M.G., Southee, J.A., McLeod, B.J. \& Haresign, W. (1986) Progesterone pre-treatment has a direct effect on GnRH-induced preovulatory follicles to determine their ability to develop into normal corpora lutea in anoestrous ewes. J. Reprod. Fert. 76, 349-363.

Hunter, M.G., Southee, J.A. \& Lamming, G.E. (1988) Function of abnormal corpora lutea in vitro after GnRH-induced ovulation in the anoestrous ewe. $J$. Reprod. Fert. 84, 139-148.

Hunter, M.G., Ayad, V.J., Gilbert, C.L., Southee, J.A.\& Wathes, D.C. (1989) Role of prostaglandin F-2a and oxytocin in the regression of GnRH-induced abnormal corpora lutea in anoestrous ewes. J. Reprod. Fert. 85, 551-556.

Inskeep, E.K., Braden, T.D., Lewis, P.E., Garcia-Winder, M. \& Niswender, G.D. (1988) Receptors for luteinizing hormone and follicle stimulating hormone in largest follicles of post-partum beef cows. Biol, Reprod. 38, 587-591.

Keisler, D.H., Inskeep, E.K. \& Dailey, R.A. (1983) First luteal tissue in ewe lambs; infiuence on subsequent ovarian activity and response to hysterectomy. I. Anim. Sci. 57, 150-156.

Kesler, D.J., Weston, P.G., Pimental, C.A., Troxel, T.R., Vincent, D.L.\& Hixon, J.E. (1981) Diminution of the in vitra response to luteinizing hormone by corporat lutea induced by gonadotropin releasing hormone treatment of post-partum suckled beef cows. J. Anint. Scí. 53, 749-754.

Knight, T.W., Tervitt, A.R. \& Fairclough, R.J. (1981) Corpus luteum function in ewes stimulated by rams. Theriogenology 15, 183-190.

Lamming, G.E., Wathes, D.C. \& Peters, A.R. (1981) Endocrine patterns of the post-partum cow. $J$. Reprod. Ferl., Suppl. 30, I55-170.

Legan, S.J., I'Anson, H., Fitzgerald, B.P. \& Akaydin, M.S., Jr (1985) Importance of short luteal phases in the endocrine mechanism controlling initiation of estrous cycles in anoestrous ewes. Endocrinology 117, $1530-1536$.

McLeod, B.J. \& Haresign, W. (1984) Evidence that progesterone may influence subsequent luteal function in the ewe by modulating pre-ovulatory follicle development. J. Reprod. Fert. 71, 381-386.

McLeod, B.J., Haresign, W. \& Lammíng, G.E. (1982) Response of seasonally anoestrous ewes to smalldose multiple injection of $\mathrm{GnRH}$ with and without progesterone pre-treatment. $J$. Reprod. Fert $\mathbf{6 5}$, $223-230$

Oldham, C.M. \& Martin, G.B. (1979) Stimulation of seasonally anovular Merino ewes by rams. II. Premature regression of ram induced corpora lutea. Anim. Reprod. Sci. 1, 291-295.

O'Shea, J.D., Rodgers, R.J. \& Wright, P.J. (1984) Morphometric analysis and function in vivo and in vitro of corpora lutea from ewes treated with $\mathrm{LHRH}$ during seasonal anoestrus. J. Reprod. Fert. 72, 75-85.

Pratt, B.R., Berardinelli, J.G., Stevens, L.P. \& Inskeep, E.K. 1982) Induced corpora lutea in the post-partum beef cow. I. Comparison of GnRH and human chorionic gonadotropin and effects of progestagen and estrogen. J. Anim. Sci. 54, 822-827.

Sheldrick, E.L. \& Flint, A.P.F. (1985) Endocrine control of uterine oxytocin receptors in the ewe. $J$. Endocr. $106,249-258$. 
Smith, M.F., Garverick, H.A., Youngquist, R.S. \& Zahler, W.L. (1986) LH receptor concentrations, adenylate cyclase activity and phosphodiesterase activity of bovine corpora lutea: comparison of short and normal estrous cycles. Dom. Anim. Endocr. 3, $127-133$.

Southee, J.A., Hunter, M.G. \& Haresign, W. (1988a) Function of abnormal corpora lutea in yivo after GnRH-induced ovulation in the anoestrous ewe. $J$. Reprod. Fert. 84, 131-137.

Southee, J.A., Hunter, M.G., Law, A.S. \& Haresign, W. (1988b) Effect of hysterectomy on the short life-cycle corpus luteum produced after GnRH-induced ovulation in the anoestrous ewe. J. Reprod. Fert. 84, I49-155.

Troxel, T.R. \& Kesler, D.J. (1984) Ability of indomethacin to alter prostaglandin metabolite concentrations and to enhance the function of corpora lutea induced in post-partum suckled beef cows. J. Anim. Sci. 59, $177-181$.

Vallet, J.L., Lamming, G.E. \& Batten, M. (1991) Control of endometrial oxytocin receptor and uterine response to oxytocin by progesterone and oestradiol in the ewe. J. Reprod. Fert. 90, 625-634.

Walton, J.S., McNeilly, J.R., McNeilly, A.S. \& Cunningham, F.J. (1977) Changes in concentrations of follicle stimulating hormone, luteinizing hormone, prolactin and progesterone in the plasma of ewes during the transition from anoestrus to breeding activity. $J$. Endocr. 75, 127-136.

White, L.M., Keisler, D.H., Dailey, R.A. \& Inskeep, E.K. (1987) Characterisation of ovine follicles destined to form subfunctional corpora lutea. $J$. Anim. Sci. 65, 1595-1601.

Wise, M.E., Glass, J.D. \& Nett, T.M. (1986) Changes in the concentration of hypothalamus and hypophyseal receptors for estradiol in pregnant and post-partum ewes. J. Anim. Sci. 62, 1021-1028.

Zollers, W.G., Garverick, H.A. \& Smith, M.F. (1989) Oxytocin-induced release of prostaglandin $F 2 \alpha$ in post-partum beef cows: comparison of short versus normal luteal phases. Biol. Reprod. 41, 262-267. 